\title{
Hubungan status vitamin D dengan mortalitas dan lama rawatan pada anak sakit kritis
}

\author{
Nice Rachmawati Masnadi, Indra Ihsan \\ Departemen IImu Kesehatan Anak Fakultas Kedokteran Universitas Andalas/RSUP M Djamil Padang
}

Korespondensi: Nice Rachmawati, email: nice rachmawati@yahoo.com

\begin{abstract}
Abstrak
Vitamin D memiliki peranan dalam pertahanan tubuh melawan infeksi. Vitamin D menghambat proliferasi sel otot polos vaskuler, melindungi endotel, dan memodulasi proses infeksi. Defisiensi vitamin $\mathrm{D}$ akan menyebabkan defek fungsi makrofag seperti kemotaksis, fagositosis, dan produksi sitokin pro-inflamasi. Defisiensi vitamin D akan memberikan luaran yang buruk pada anak sakit kritis. Tujuan: Untuk mengetahui hubungan kadar dan status vitamin D terhadap mortalitas dan lama rawatan pada anak sakit kritis. Metode: Studi potong lintang dilakukan di PICU RSUP M. Djamil Padang sejak Agustus sampai November 2016. Dilakukan penghitungan skor Pelod-2, pemeriksaan kadar serum vitamin $\mathrm{D}$ dan kalsium, dan dihubungkan dengan mortalitas serta lama rawatan. Hubungan antar variabel dianalisis statistik menggunakan t-Test, Mann-Whitney, Chi-square dan Kruskal-Wallis. Hasil: Diperoleh prevalensi insufisiensi dan defisiensi vitamin D pada anak sakit kritis adalah $37,50 \%$ dan 44,64\%. Dari 56 subjek, 19 subjek meninggal dunia (33,92\%). Skor Pelod 2 pada awal rawatan berhubungan dengan mortalitas $(p=0,001)$. Tidak terdapat hubungan antara status vitamin $D$ dengan mortalitas $(p=0,732)$ dan lama rawatan $(p=0,311)$ pada anak sakit kritis. Simpulan: Bahwa sebagian besar anak sakit kritis mengalami insufisiensi dan defisiensi vitamin $D$, namun status vitamin $D$ tidak berhubungan dengan tingkat mortalitas dan lama rawatan.
\end{abstract}

Kata kunci: defisiensi vitamin D; anak sakit kritis; mortalitas; lama rawatan

\section{Abstract}

Vitamin D has role in the body's defense against infection. Vitamin D inhibits proliferation of vascular smooth muscle cells, endothelial protect, and modulate the process of infection. Deficiency of vitamin $D$ will cause defects of macrophage functions such as chemotaxis, phagocytosis and production of proinflammatory cytokines. Deficiency of vitamin D will provide poor outcomes in critically ill children. Objective: To know the relationship levels of vitamin $D$ and vitamin $D$ status on mortality and length of stay in critical ill children. Methods: Cross-sectional study conducted in the PICU Dr. M. Djamil Padang since August to November 2016. Perform of scoring Pelod-2, checking serum levels of vitamin $D$ and calcium, these variables are associated with mortality and length of stay. The relationships among variables analyze using t-test, Mann-Whitney, Chi-square, and Kruskal-Wallis. Results: The prevalence of vitamin D insufficiency and deficiency in critical ill children was $37.50 \%$ and $44.64 \%$. Of the 56 subjects, 19 subjects died (33.92\%). Mortality associated with the score Pelod 2 at the start of treatment ( $p=0.001)$. There was no relationship between vitamin $D$ status and mortality $(p=0.732)$ and duration of treatment ( $p=0.311)$ in critical ill children. Conclusion: Most of critical ill children were experiencing vitamin D insufficiency and deficiency. Vitamin D status was not associated with mortality and length of stay.

Keywords: vitamin D deficiency; critically ill children; mortality; length of stay 


\section{PENDAHULUAN}

Vitamin D merupakan hormon steroid yang berperan penting pada pengaturan kadar kalsium dan fosfat serum, dan mineralisasi tulang. ${ }^{1}$ Vitamin D dari di kulit dan dari diet di metabolisme di hati menjadi 25(OH)-D, yang sering digunakan untuk menentukan status vitamin D pasien, kemudian $25(\mathrm{OH})$ $D$ dimetabolisme di ginjal dengan bantuan enzim 25-hidroksivitamin D-1 $\alpha$-hidroksilase (CYP27B1) menjadi bentuk aktif yaitu 1,25-dihidroksivitamin D. Penelitian terkini membuktikan vitamin $\mathrm{D}$ berperan dalam fungsi pertahanan tubuh, baik dalam imunitas alamiah (innate) maupun adaptif. $^{2}$ Beberapa penelitian menunjukkan bahwa vitamin $D$ berperan luas dalam pertahanan tubuh terhadap penyakit infeksi, alergi, keganasan, dan autoimun. ${ }^{3-5}$

Defisiensi vitamin $\mathrm{D}$ berhubungan dengan kejadian infeksi saluran pernapasan atas dan bawah oleh berbagai penyebab, terutama virus dan sepsis. ${ }^{3-9}$ Sel makrofag, limfosit dan sel dendrit yang berperan pada sistem imun bawaan dan adaptif makrofag, limfosit dan sel dendrit mengekspresikan reseptor vitamin $D$ dan merespons terhadap stimulasi 1,25$(\mathrm{OH}) 2 \mathrm{D}$. Prevalensi vitamin D pada pasien dengan infeksi berat cukup tinggi dan defisiensi vitamin $D$ berhubungan dengan angka mortalitas yang lebih tinggi. ${ }^{2,3}$ Mekanisme peningkatan mortalitas pada pasien rawatan ICU dengan hipovitaminosis $D$ berhubungan dengan fungsi pleiotropik vitamin D. Vitamin D menghambat proliferasi sel otot polos vaskuler, melindungi fungsi endotel normal, dan memodulasi proses inflamasi. ${ }^{10}$

Defisiensi vitamin D berhubungan dengan derajat keparahan penyakit, bakteremia, dan mortalitas yang tinggi pada penderita sakit kritis. ${ }^{3,4}$ Penelitian pada anak sakit kritis, termasuk kasus bedah dan nonbedah, di Kanada mendapatkan prevalensi defisiensi vitamin D adalah 69\% dan prevalensi insufisiensi adalah $23 \%{ }^{3}$ Sementara di Sydney ditunjukkan tingkat insufisiensi dan defisiensi vitamin $D$ masing-masing 55\% dan 38\%, serta kadar vitamin D yang tidak terdeteksi $17 \% .^{5}$ Penelitian di Israel melaporkan tingkat defisiensi vitamin $D$ pada sakit kritis sebesar 82,3\%, ${ }^{6}$ dan di Colorado defisiensi dan insufisiensi vitamin D adalah $26 \%$ dan $50 \%{ }^{7}$

Penelitian vitamin D pada anak sakit kritis di Indonesia baru pertama kali dipublikasikan oleh Utami dkk. (2015), yang melaporkan bahwa kadar serum vitamin $D$ rerata pada anak sakit kritis adalah 11,46 $\mathrm{ng} / \mathrm{ml}$, lebih rendah dibandingkan dengan anak sakit non-kritis $(25,98 \mathrm{ng} / \mathrm{ml})$ dan terdapat korelasi kuat antara sakit kritis dan kadar vitamin $D$ rendah $(r=-0,624$, $p<0.001){ }^{8}$ Penelitian ini bertujuan untuk mengetahui status vitamin $D$ dan hubungannya dengan lama rawatan dan mortalitas pada anak sakit kritis yang dirawat di PICU RSUP M. Djamil Padang.

\section{METODE}

Penelitian ini merupakan suatu penelitian cross-sectional analytic yang dilakukan pada semua anak sakit kritis yang dirawat 
di PICU RSUP Dr M Djamil Padang pada bulan Juli sampai Desember 2016. Pemeriksaan sampel dilakukan di laboratorium Prodia Padang. Perkiraan besar sampel menggunakan rumus besar sampel untuk proporsi:

$$
n=\frac{(Z \alpha)^{2} \times P \times Q}{d^{2}}=55,96=56
$$

Berdasarkan rumus ini maka diperlukan sampel minimal sejumlah 56 orang. Pemilihan sampel dilakukan secara purposive sampling. Kriteria inklusi adalah pasien anak sakit kritis yang dirawat di PICU RSUP M Djamil dan menandatangani informed concent. Kriteria eksklusi adalah menderita penyakit HIV, gagal fungsi hati kronik, penyakit ginjal kronik dan pasien sakit kritis akibat trauma, keganasan, penyakit autoimun dan malnutrisi berat. Izin penelitian diperoleh melalui komite penelitian Fakultas Kedokteran Unand.

Prosedur pengambilan sampel darah dilakukan oleh peneliti, petugas laboratorium atau dibantu PPDS pada saat awal pasien masuk ke PICU. Sampel darah yang dibutuhkan sebanyak $3 \mathrm{cc}$ darah vena diambil menggunakan spuit $3 \mathrm{cc}$ merk Terumo. Sampel darah yang telah diambil dimasukkan ke dalam tabung khusus dan langsung dikirim ke laboratorium Prodia Padang untuk pemeriksaan kadar 25$(\mathrm{OH})$ D plasma. Prosedur pemeriksaan 25(OH)D: $50 \mu \mathrm{l}$ sampel dimasukkan ke dalam setiap well kalibrator, inkubasi selama 1 jam kemudian tambahkan $1 \mathrm{ml}$ larutan 25$\mathrm{D}$ biotin ke dalam seluruh tabung. Vortek tabung selama 10 detik. $200 \mu$ kalibrator, kontrol, dan sampel yang telah diencerkan dimasukkan ke dalam well pada plate yang telah terselimuti dengan antibodi (antibody coated plate). Tempatkan plate lid pada plate dan tutup plate dengan plastik. Inkubasi pada suhu $18-25^{\circ} \mathrm{C}$ selama 2 jam. Seluruh well dicuci sebanyak 3 kali dengan wash solution. Set plate washer sebanyak minimal $300 \mu l$ wash solution setiap well. Ditambahkan $200 \mu \mathrm{L}$ enzyme conjugate pada semua well dengan menggunakan multichannel pipette. Tempatkan plate lid pada plate dan tutup plate dengan plastik. Inkubasi pada suhu 18-250C selama 30 menit. Ditambahkan 10 $\mu \mathrm{l}$ stop solution pada semua well dengan menggunakan multichannel pipette. Absorben dari tiap well diukur pada 450 $\mathrm{nm}$ (referens 650nm) menggunakan microplate reader dalam waktu 30 menit setelah penambahan stop solution.

\section{HASIL DAN PEMBAHASAN}

Pada periode penelitian terdapat 56 subjek yang memenuhi kriteria inklusi dengan karakteristik subjek dapat dilihat pada Tabel 1. Prevalensi defisiensi dan insufisiensi vitamin $D$ pada penelitian ini adalah 44\%, 64\%, dan 37,50\% dimana terdapat 3 subjek dengan kadar vitamin $D$ tidak terukur $(<4 \mathrm{ng} / \mathrm{ml})$.

Dari 56 subjek, 19 orang (33,92\%) meninggal dunia. Kadar rerata serum vitamin $D$ pada kelompok yang meninggal dunia lebih rendah dibandingkan kelompok yang bertahan hidup, namun secara statistik perbedaan ini tidak bermakna $(p>0,05)$. Hasil uji Chi-Square for trend (Tabel 3) menunjukkan bahwa tidak 
terdapat hubungan antara status vitamin D dengan mortalitas pada anak sakit kritis $(p>0,05)$.

Tabel 1. Karakteristik subjek.

\begin{tabular}{|c|c|}
\hline Karakteristik subjek & Jumlah (persentase) $(n=56)$ \\
\hline \multicolumn{2}{|l|}{ Jenis kelamin } \\
\hline Laki-laki & $23(41,07)$ \\
\hline Perempuan & $33(58,93)$ \\
\hline \multicolumn{2}{|l|}{ Usia } \\
\hline$<1$ tahun & $21(37,50)$ \\
\hline 1-5 tahun & $15(26,78)$ \\
\hline$>5$ tahun & $20(35,71)$ \\
\hline \multicolumn{2}{|l|}{ Status Gizi } \\
\hline Gizi baik & $17(30,35)$ \\
\hline Gizi kurang & $27(48,21)$ \\
\hline Gagal tumbuh & $12(21,42)$ \\
\hline \multicolumn{2}{|l|}{ Status vitamin D } \\
\hline Normal & $10(17,80)$ \\
\hline Insufisiensi & $21(37,50)$ \\
\hline Defisiensi & $25(44,64)$ \\
\hline Kadar Vitamin D & 19,72 (SD 11,15) \\
\hline Kadar Kalsium Serum & $8,56(8,10-9,02)$ \\
\hline Skor Pelod 2 & $2(1-13)$ \\
\hline \multicolumn{2}{|l|}{ Diagnosis } \\
\hline Syok sepsis & 11 \\
\hline Pneumonia & 8 \\
\hline Meningitis & 7 \\
\hline Ensefalitis & 6 \\
\hline Gagal jantung & 2 \\
\hline Pneumonia + Kelainan jantung & 3 \\
\hline Ketoadisosis Diabetikum & 3 \\
\hline Dengue ensefalopati & 2 \\
\hline Malaria Berat & 1 \\
\hline Krisis hipertensi & 1 \\
\hline Keganasan & 5 \\
\hline Periodik paralisis & 1 \\
\hline Myelitis transversa & 1 \\
\hline Asma dengan ancaman gagal nafas & 1 \\
\hline Empiema + Pemasangan WSD & 1 \\
\hline TEN & 1 \\
\hline Surgikal & 2 \\
\hline
\end{tabular}

Dari 37 sampel pada kelompok yang bertahan hidup, median lama rawatan pada kelompok dengan status vitamin D normal, insufisiensi dan defisiensi berturut turut adalah; 7 (2-21) vs 11(5-34) vs (7-23) hari. Namun secara statistik (Uji KruskalWallis) perbedaan ini tidak bermakna signifikan $(p=0,311)$. 
Penelitian ini mendapatkan 82,14\% anak sakit kritis memiliki status vitamin D prehospital yang rendah, terdiri dari $37,50 \%$ subyek mengalami insufisiensi dan 44,64\% subyek mengalami defisiensi. Prevalensi defisiensi vitamin $D$ pada anak sakit kritis mencapai $30-70 \% .{ }^{1,2,9,10}$ Tingkat defisiensi vitamin $D$ pada penelitian ini lebih tinggi dibandingkan penelitian Rey dkk. $(29,5 \%),{ }^{11}$ Rippel dkk. (34,5\%), ${ }^{10}$ hampir sama jika dibandingkan dengan penelitian Madden dkk. (40\%), namun lebih rendah dibandingkan penelitian Elmoneim dkk. $(56,7 \%)$ dan Mc Nally dkk. (69\%).

Tabel 2. Kadar vitamin D, kalsium, skor pelod 2 dan lama rawatan pada kelompok pasien yang bertahan hidup dibandingkan yang meninggal dunia.

\begin{tabular}{lccc}
\hline Variabel & $\begin{array}{c}\text { Hidup } \\
(\mathrm{n}=37) \\
\text { Mean }( \\
\text { SD) }\end{array}$ & $\begin{array}{c}\text { Meninggal } \\
(\mathrm{n}=19)\end{array}$ & Nilai $\mathrm{Mean} \pm \mathrm{SD}$ \\
& & \\
\hline Kadar & $21,04($ & 17,15 & $0,218^{*}$ \\
Vitamin D & $10,21)$ & $(12,67)$ & \\
Kadar & $8,7(6,9-$ & $8,3(3,8-$ & $0,105^{* *}$ \\
Kalsium & $17,7)$ & $10,1)$ & \\
Serum & & & \\
Skor Pelod & $1(1-13)$ & $7(1-11)$ & $0,001^{* *}$ \\
& & & \\
\hline
\end{tabular}

*t-test, ${ }^{* *}$ Mann-Whitney

Banyak faktor yang mempengaruhi status vitamin D pre-hospital diantaranya adalah paparan sinar matahari, perbedaan warna kulit, ras, asupan nutrisi dan konsumsi suplemen vitamin D serta status gizi, di samping itu pada penyakit tertentu juga diketahui memiliki kecenderungan menderita defisiensi vitamin $D$ melalui mekanisme spesifik, seperti pada gangguan ginjal kronik, post-operasi jantung, dan sepsis. Hal ini terlihat pada penelitian
Elmoneim yang mendapatkan tingginya tingkat defisiensi vitamin $\mathrm{D}$ disebabkan karena sebahagian besar $(76,5 \%)$ pasien pada kelompok defisiensi merupakan pasien yang mengalami gangguan fungsi ginjal. Penelitian McNally dkk. mendapatkan hampir sebagian besar pasien merupakan pasien post-operasi jantung.

Tabel 3. Hubungan status vitamin $D$ dengan mortalitas pada anak sakit kritis.

\begin{tabular}{|c|c|c|c|c|}
\hline \multirow[t]{2}{*}{ Mortalitas } & \multicolumn{3}{|c|}{ Status vitamin D } & \multirow{2}{*}{$\begin{array}{c}\text { Nilai } \\
p\end{array}$} \\
\hline & $\begin{array}{l}\text { Nor- } \\
\text { mal }\end{array}$ & $\begin{array}{c}\text { Insufisi- } \\
\text { ensi }\end{array}$ & $\begin{array}{c}\text { Defisi- } \\
\text { ensi }\end{array}$ & \\
\hline Hidup & 6 & 16 & 15 & \\
\hline Meninggal & 4 & 5 & 10 & \\
\hline
\end{tabular}

*** Uji Chi-Square for trend

Beberapa studi menunjukkan adanya hubungan antara defisiensi vitamin D dengan peningkatan mortalitas, pada pasien sakit kritis, tetapi beberapa studi lain melaporkan hal sebaliknya. ${ }^{10,11}$ Defisiensi vitamin $D$ akan meningkatkan risiko kematian 1,9 kali lipat $(\mathrm{Cl}=1,15-2,98$; $\mathrm{p}=0,01)^{12}$ dan kadar vitamin $\mathrm{D} 12 \mathrm{ng} / \mathrm{ml}$ merupakan cut of point peningkatan risiko kematian pada anak sakit kritis. ${ }^{9}$ Defisiensi vitamin $D$ menyebabkan peningkatan morbiditas dan mortalitas melalui efek pleiotropik terhadap fungsi multi organ, dan juga efek terhadap sistem imun, baik sistem imun alamiah ataupun adaptif. 7,8 Defisiensi vitamin $D$ akan memicu terjadinya disfungsi multi organ pada pasien sakit kritis dan secara tidak langsung meningkatkan risiko morbiditas dan mortalitas. ${ }^{1,2}$ 
Kadar Vitamin D

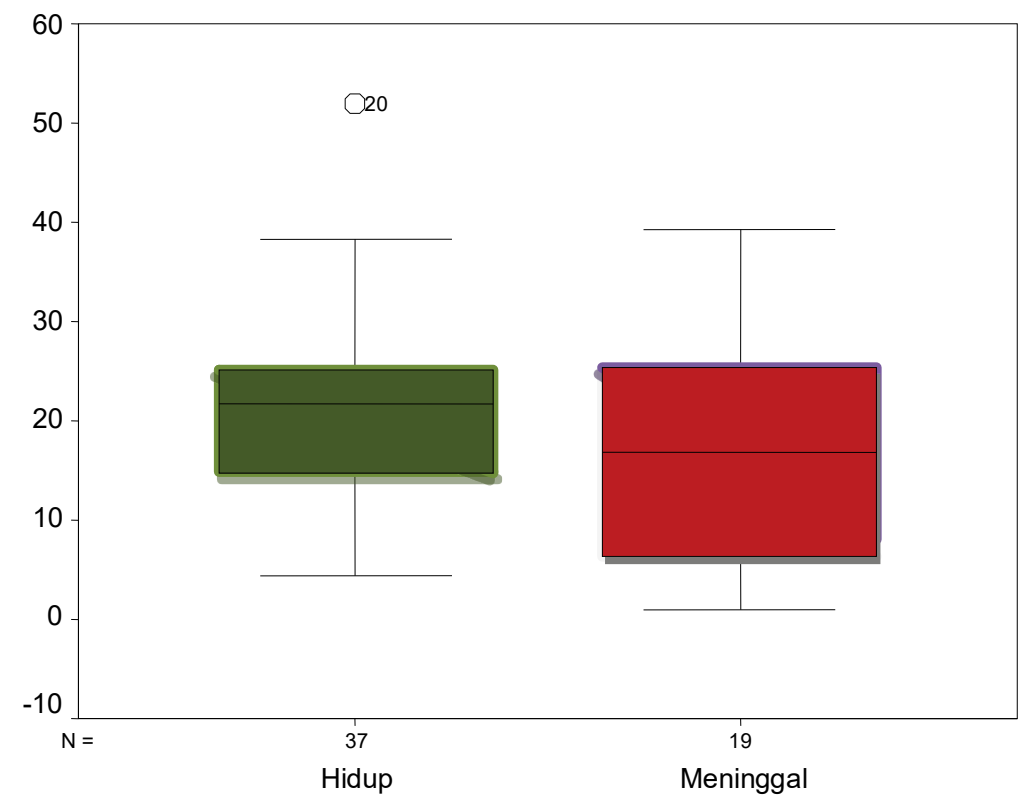

Luaran

Gambar 1. Kadar rerata serum vitamin D kelompok yang bertahan hidup dan meninggal.

Defisiensi vitamin D juga menghambat maturasi makrofag sehingga produksi lisozim dan $\mathrm{H} 2 \mathrm{O} 2$ yang memiliki efek antimikrobial menjadi menurun. ${ }^{13}$ Penelitian Moraes dkk., melaporkan bahwa Defisiensi vitamin $D$ juga berhubungan dengan peningkatan lama rawatan, kebutuhan ventilasi mekanik, resusitasi cairan dan inotropik pada anak sakit kritis. ${ }^{3}$ Pada penelitian ini walaupun kadar rerata vitamin D pada kelompok subjek yang meninggal lebih rendah dibanding kelompok yang bertahan hidup namun secara statistik perbedaan ini tidak bermakna demikian juga tidak ada hubungan status vitamin $D$ dengan tingkat mortalitas. Demikian juga halnya dengan lama rawatan, walaupun terdapat perbedaan lama rawatan pada kelompok yang bertahan hidup, namun secara statistik perbedaan tersebut tidak signifikan. Hal ini kemungkinan disebabkan karena jumlah sampel yang kurang. Kemungkinan ini diperkuat dengan fakta bahwa terdapat 3 subjek pada penelitian ini dengan kadar serum vitamin D yang tidak terdeteksi $(<4 \quad \mathrm{ng} / \mathrm{ml})$ dan ketiganya meninggal dunia. 


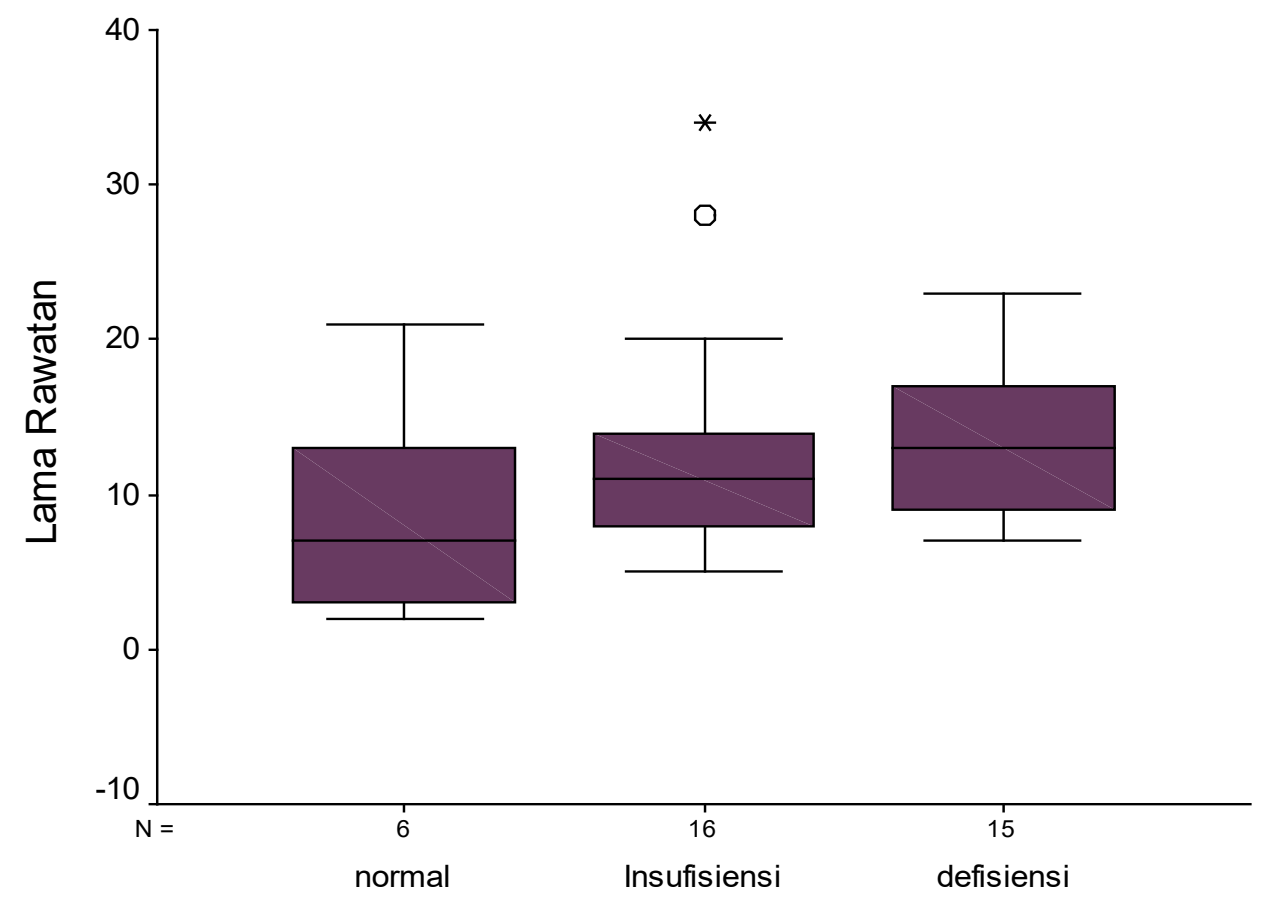

Status Vitamin D

Gambar 2. Perbedaan lama rawatan berdasarkan status vitamin D

Kendala utama dan keterbatasan pada penelitian ini dan juga penelitian lainya adalah tidak adanya data awal kadar vitamin $D$ sebelum sakit, sulitnya menghitung asupan vitamin $\mathrm{D}$ dan menilai tingkat paparan sinar matahari secara individual sehingga tidak bisa ditentukan faktor yang lebih berperan menyebabkan rendahnya kadar serum vitamin $D$, apakah memang disebabkan oleh pengaruh keparahan penyakit secara langsung atau mungkin pasien justru sudah mengalami defisiensi sebelum sakit akibat asupan nutrisi dan paparan cahaya matahari yang tidak adekuat. Keterbatasan lain penelitian ini di antaranya: jumlah sampel yang kurang banyak dibanding penelitian lainya, waktu penelitian yang pendek, dan diagnosis yang heterogen. Pada studi selanjutnya pengukuran kadar serum vitamin D sebaiknya dilakukan berkala untuk melihat pengaruh keparahan penyakit terhadap status vitamin D serum serta perlu dilakukan uji eksperimental suplementasi vitamin D pada anak sakit kritis sehingga dapat terlihat peranan nyata vitamin D terhadap sistem imun.

\section{KESIMPULAN}

Sebagian besar anak sakit kritis memiliki status vitamin D pre-hospital rendah. Status vitamin $D$ tidak berhubungan dengan tingkat mortalitas dan lama rawatan. 


\section{DAFTAR PUSTAKA}

1. Madden K, Fieldman HA, Smith EM, Gordon CM, Keisling SM, et al. Vitamin D deficiency in critically ill children. Pediatrics 2012; 130:421-8.

2. McNally JD, Menon K, Chakraborty P, Fisher L, Williams KA, Al-Dirbashi OY, et al. Canadian Critical Care Trials Group. The association of vitamin D status with pediatric critical illness. Pediatrics 2012; 130:429-36.

3. Sankar J, Lotha W, Ismail J, Anubuthi C, Meena RS, Sankar J. Vitamin D deficiency and length of pediatric intensive care unit stay: a prospective observational study. Ann Intensive Care 2016; 3:1-9.

4. Elmoneim AA, Rhill RM, Rahalli MA, Al-Rahalli ML, Alrehally AS, Alrohily SK, et al. Vitamin D level in pediatric intensive care unit (PICU) patients: its relation to severity of illness. Pediat Therapeut 2016; 6:1-4.

5. Lucidarme O, Messai E, Mazzoni T, Arcade M, du Cheyron D. Incidence and risk factors of vitamin $D$ deficiency in critically ill patients: results from a prospective observational study. Intensive Care Med 2010; 36:1609-11.

6. McNally JD, Menon K, Lawson MI, Williams K, Doherty DR. 1,25-dihydoxyvitamin D levels in pediatric intensive care units: risk factors and association with clinical course. J Clin Endocrinol Metab 2015; 100:2942-5.

7. Samuel S, Sitrin MD. Vitamin D's role in cell proliferation and differentiation. Nutr Rev 2008; 66:S116-24.

8. Ayulo M Jr, Katyal Ch, Agarwal Ch, Sweberg T, Rastogi D, Markowitz M, et al. The prevalence of vitamin $D$ deficiency and its relationship with disease severity in an urban pediatric critical care unit. Endocr Regul. 2014; 48:69-76.

9. Moraes RB, Friedman G, Wawrzeniak LW, Marques LS, Nagel FM, Lisboa TC, et al. Vitamin D deficiency is independently associated with mortality among critically ill patients. Clinics Sao Paulo 2015; 70:326-32.

10. Rippel C, South M, Butt WW, Shekerdemian LS. Vitamin D status in critically ill children. Intensive Care Med 2012; 38:2055-62.

11. Rey C, Sánchez-Arango D, López-Herce J, et al. Vitamin D deficiency at pediatric intensive care admission. J Pediatr (Rio J) 2014; 90:135-42.

12. Braun AB, Gibbons FK, Litonjua AA, Giovannucci E, Christopher KB. Low serum 25hydroxyvitamin $D$ at critical care initiation is associated with increased mortality. Crit Care Med 2012; 40:63-72.

13. Abu-Amer Y, Bar-Shavit Z. Regulation of TNF-alpha release from bone marrow-derived macrophages by vitamin D. J Cell Biochem 1994; 55:435-44. 